\title{
Adsorption isotherms of methanol and dimethyl ether on SAPO-34 measured together with differential adsorption heat measurement
}

\author{
Yasukazu Kobayashi, Yuxin Li, Yao Wang, Dezheng Wang* \\ Department of Chemical Engineering, Tsinghua University, Beijing 100084, China
}

\section{A R T I C L E I N F O}

\section{Article history:}

Received 30 June 2013

Accepted 13 August 2013

Published 20 December 2013

\section{Keywords:}

Dual-site Langmuir equation

Methanol adsorption

Dimethyl ether adsorption

Differential heat of adsorption

SAPO-34 zeolite

\begin{abstract}
A B S T R A C T
Adsorption isotherms of methanol and dimethyl ether on a SAPO-34 zeolite were measured at 25, 60 , and $100{ }^{\circ} \mathrm{C}$. The curves of differential heats of adsorption versus coverage (calorimetric curves) were simultaneously measured with a microcalorimeter, which showed that a simple interpretation of the adsorption isotherms would be incorrect. The calorimetric curves showed sharp drops, and the coverages at which these occurred were taken as the saturation amounts of adsorbed methanol and dimethyl ether on regular sites. However, beyond the saturation coverage, the adsorption isotherms still showed increasing coverages, which were attributed to adsorption on weaker sites, and which should not be used during curve fitting to get the Langmuir parameters of the adsorption isotherm for the regular adsorption sites. In the absence of the calorimetric data, these regions would have been assumed to be part of the adsorption isotherm for the regular adsorption sites, which would be erroneous. To account for the existence of another weaker adsorption site which continued to be populated at high pressures, in addition to the regular adsorption site, we used the dual-site Langmuir equation with the saturation amount on the regular adsorption site obtained from the calorimetric curves. This gave good fits also in the high pressure region where adsorption mainly occurred on the weaker sites.
\end{abstract}

(C) 2013, Dalian Institute of Chemical Physics, Chinese Academy of Sciences. Published by Elsevier B.V. All rights reserved.

\section{Introduction}

In reaction kinetics, Langmuir theory is widely used to calculate the surface concentrations as a function of the pressure using the parameters of saturation coverage $\left(N_{\text {ad,sat }}\right)$ and adsorption equilibrium constant $(b)$ [1]. For high temperature reactions, the adsorption isotherms of many component gases have to be measured at much lower temperatures to avoid reactions of the adsorbate, and the adsorption equilibrium constant is then extrapolated to the reaction temperature [2]. Generally, the isotherm parameters are obtained by fitting the Langmuir equation with data points measured in adsorption experiments without using any other information on the chem- istry of the adsorption sites. In this study, we report that this simple approach would give wrong parameters when the adsorbate adsorbs to coverages that exceed the saturation coverage, and in this case, an independent measurement is needed to get the saturation coverage. This was obtained here by the measurement of the curve of adsorption heat versus coverage (calorimetric curve) simultaneously using microcalorimetry. A Tian-Calvet heat flux microcalorimeter was combined with the volumetric manometry apparatus for adsorption isotherm measurement because it had been shown that the measurement of the calorimetric curve gives information on adsorption site strength and its distribution, which makes microcalorimetry a powerful tool for characterizing the surfaces of catalyst

\footnotetext{
*Corresponding author. Tel: +86-10-62794467; Fax: +86-10-62772051; E-mail: wangdezheng@tsinghua.edu.cn This work was supported by the National Natural Science Foundation of China (21173125). 
powders [3-6].

The catalyst used in this study is SAPO-34 zeolite, which is being intensively studied for the methanol-to-olefins (MTO) process for light olefin production from methanol [7]. This process is operated at high temperature $\left(>350{ }^{\circ} \mathrm{C}\right)$, so the adsorption isotherms of methanol and dimethyl ether (DME) measured at the lower temperatures of 25,60 , and $100{ }^{\circ} \mathrm{C}$ need to have their Langmuir parameters extrapolated to $>350{ }^{\circ} \mathrm{C}$ for use in the reaction kinetics.

\section{Experimental}

\subsection{Sample preparation and characterization}

The catalyst was synthesized by the hydrothermal method using a recipe for the synthesis of SAPO-34 zeolite, but characterization showed that it was actually a mixed crystal zeolite that was composed of microporous SAPO-34 and SAPO-18. Reaction studies showed that its chemistry is basically the same as that of the SAPO-34 zeolite used in the MTO process. The reagents used in the initial gel mixture were triethylamine (TEA) as the organic template, and pseudoboehmite (73 wt $\%$ $\mathrm{Al}_{2} \mathrm{O}_{3}$ ), silica sol (40 wt\% $\mathrm{SiO}_{2}$ ), and orthophosphoric acid (85 wt $\% \mathrm{H}_{3} \mathrm{PO}_{4}$ ), respectively, as the source materials of $\mathrm{Al}, \mathrm{Si}$, and P. A homogeneous gel with the composition of $\mathrm{Al}_{2} \mathrm{O}_{3}: \mathrm{P}_{2} \mathrm{O}_{5}: \mathrm{SiO}_{2}$ : TEA: $\mathrm{H}_{2} \mathrm{O}=1: 1.15: 0.19: 2.7: 114$ was sealed inside a hydrothermal synthesis autoclave and allowed to crystallize hydrothermally under its endogenous pressure at $200{ }^{\circ} \mathrm{C}$ for $20 \mathrm{~h}$. After the crystallization reaction, the crystals were recovered by centrifuging, washed several times, and then dried at $80^{\circ} \mathrm{C}$ for $8 \mathrm{~h}$, which was followed by calcination at $600{ }^{\circ} \mathrm{C}$ for $4 \mathrm{~h}$ to get the zeolite.

The crystal structure of the sample was characterized by X-ray diffraction (XRD, Bruker D8/Advance). $\mathrm{Cu} K_{\alpha}$ radiation was used as the X-ray source. Diffraction intensities were recorded from $5^{\circ}-45^{\circ}$ at the rate of $5^{\circ} / \mathrm{min}$. The observed diffraction patterns were assigned by referring to the Joint Committee on the Powder Diffraction Standards (JCPDS) card. Elemental analysis of the sample was performed by X-ray energy-dispersive spectroscopy (EDS). Its pore structure was characterized by its argon adsorption isotherm at $-186{ }^{\circ} \mathrm{C}$ (Quantachrome Instruments, Autosorb $\mathrm{iQ}_{2}$ ). Its pore volume and pore width distribution were calculated by the density functional theory (DFT) method. The morphology of the zeolite was characterized by scanning electron microscopy (SEM) (JSE-6700F, JEOL). Acid site density was calculated from ammonia temperature-programmed desorption ( $\mathrm{NH}_{3}$-TPD) measurement. The sample was first heated up to $400{ }^{\circ} \mathrm{C}$ under He flow and kept for $3 \mathrm{~h}$. After cooling down to $100{ }^{\circ} \mathrm{C}$, it was exposed to $\mathrm{NH}_{3}$ flow for $1 \mathrm{~h}$ and then to He flow for $1 \mathrm{~h}$ to remove excess $\mathrm{NH}_{3}$. Then, the temperature was increased up to $800{ }^{\circ} \mathrm{C}$ at the rate of $10{ }^{\circ} \mathrm{C} / \mathrm{min}$. The desorption signal of $\mathrm{NH}_{3}$ from the sample was detected by a thermal conductivity detector. The acid site density was also calculated from the EDS analysis of the Si/Al ratio.

\subsection{Apparatus for chemisorption experiments}

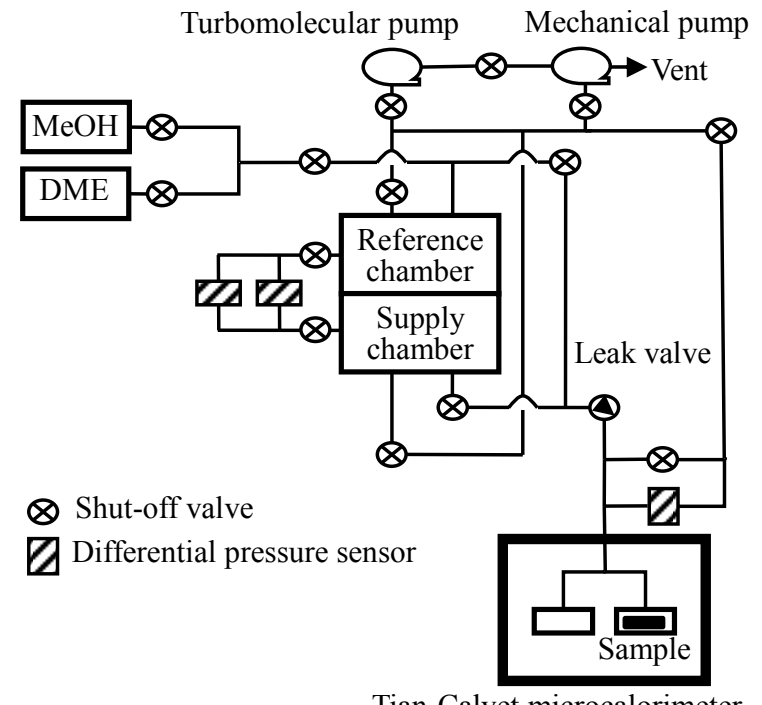

Tian-Calvet microcalorimeter

Fig. 1. Schematic of apparatus comprising gas adsorption manometry and Tian-Calvet microcalorimetry.

Chemisorption experiments of methanol and DME were conducted with a homemade volumetric manometry apparatus. Figure 1 is a schematic of the homemade apparatus comprising a gas adsorption manometer and a Tian-Calvet microcalorimeter. Details of the manometry apparatus were described in a previous report [8]. It was specially constructed to give high resolution isotherm data by a continuous dosing procedure, but in this work it was only used with the more conventional discontinuous dosing procedure.

The heat flow microcalorimeter, shown in Fig. 2, was specially constructed for a rapid heat response that was obtained by minimizing the length of the heat flow path from the sample powder to the surface of the thermopile, which was separated from the sample by only a $0.5 \mathrm{~mm}$ thick wall of the stainless steel cell. It was based on the design by Handy et al. [9], but with the modification that flat thermopiles were used instead of their thimble-shaped thermopiles. This allowed sample powder
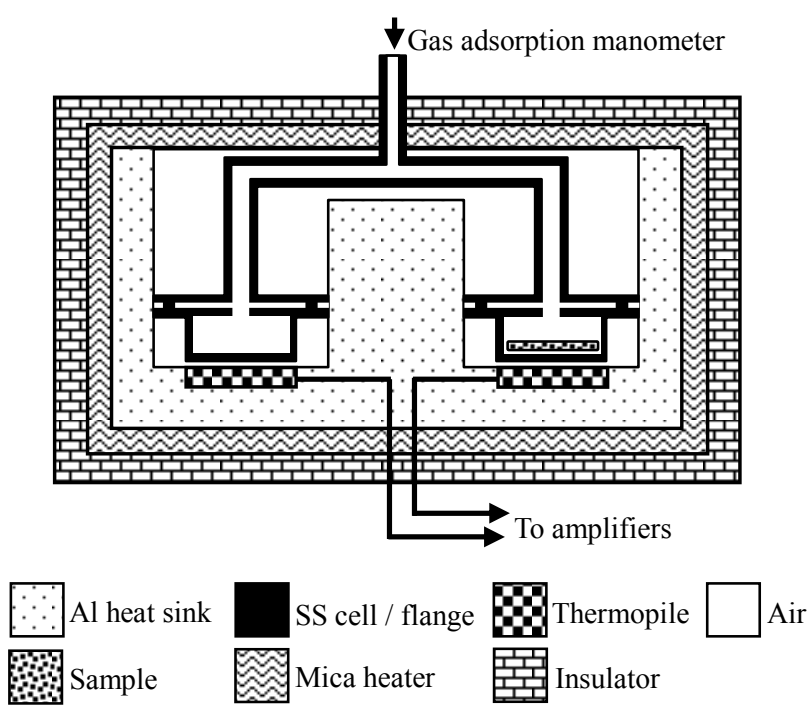

Fig. 2. Schematic of the Tian-Calvet microcalorimeter. 
particles to be distributed as a very thin layer of less than $1 \mathrm{~mm}$ thickness to get a quicker time response from gas adsorption on the sample. The thermopiles were purchased from International Thermal Instruments Corp. (Model BHT). The voltages from the thermopiles were amplified by amplifiers purchased from Nanjing University (Model ND-802). The output signals from the amplifiers were recorded by an analog-to-digital conversion board in a personal computer.

Electric calibration was used to get the sensitivities of the microcalorimeter at 25,60 , and $100{ }^{\circ} \mathrm{C}$, which were used to convert the voltage signal into energy units. In the calibration, a $1005 \Omega$ resistor placed on the center of the sample cell was connected by copper rods of $1 \mathrm{~mm}$ diameter to a DC voltage generator (R6144, ADVANTEST, Japan) that was switched on for fixed periods to heat it. The supply of 1,2 , or $3 \mathrm{~V}$ to the resistor for specific periods gave heat response curves, and the areas under these curves were used to get the sensitivity factors. The calibration showed that the baseline was stable enough to measure a minimum heat of $0.1 \mathrm{~mW}$. Good linear correlations between the area under the heat curve and the heat dissipated by the resistor were obtained at all the temperatures used. The sensitivities at 25,60 , and $100{ }^{\circ} \mathrm{C}$ were 18.99 , 19.21 , and $17.31 \mathrm{mV} / \mathrm{W}$, respectively.

Before the adsorption experiments, the sample was pretreated at $400{ }^{\circ} \mathrm{C}$ for $5 \mathrm{~h}$ under $1 \times 10^{-5} \mathrm{~Pa}$. In each dose of a small amount of gas into the sample cell, when $d n$ gas amount was adsorbed, the adsorption heat $(d Q)$ evolved was measured by the thermopile, and the differential heat of adsorption was calculated by $d Q / d n$.

\section{Results and discussion}

\subsection{Sample characterization}

Figure 3 shows the XRD pattern of the zeolite used in this study. A comparison with the XRD pattern of the standard reference for SAPO-34 showed that our sample had the difference that the separation between the peaks at $30.8^{\circ}$ and $31.2^{\circ}$ was not obvious. These broadened XRD peaks indicated that it was an intergrowth crystalline structure, and to better understand this, the XRD pattern of the catalyst was simulated using DIF-

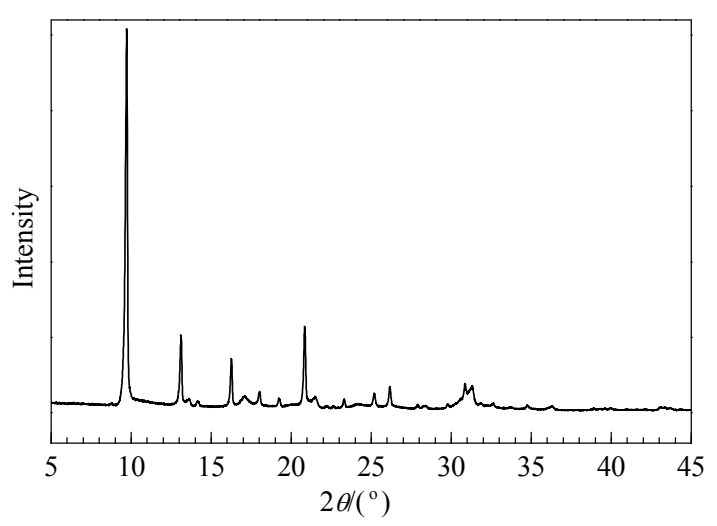

Fig. 3. XRD pattern of the SAPO-34 zeolite.

FaX [10], a specialized computer program for studying crystals with stacking faults, which indicated that the sample was an intergrowth structure of the CHA/AEI structures, namely, a SAPO-34 and SAPO-18 intergrowth crystal, with a CHA to AEI structure ratio of 8:2. Reactivity studies showed that its reaction behavior is similar to that of SAPO-34, with the small difference that it gave a slightly higher propene selectivity. Its adsorption behavior for methanol and DME is expected to be similar to that of SAPO-34, thus it will be called SAPO-34 because the interest here is in its MTO chemistry.

The Ar adsorption isotherm for the zeolite sample is shown in Fig. 4. A small hysteresis loop was present, which indicated the existence of some mesoporous pores. The physical adsorption data were used to get the physical properties of the sample by DFT calculations. The surface area, total pore volume, and average pore width were $1247 \mathrm{~m}^{2} / \mathrm{g}, 0.297 \mathrm{~mL} / \mathrm{g}$, and 0.552 $\mathrm{nm}$, respectively. In the SEM image (Fig. 5), cubic crystals were observed, which probably reflected the rhombohedral symmetry of the CHA structure. The crystal particles were 1 to 2 $\mu \mathrm{m}$ in size. The SEM images showed some holes in the crystals, which were probably the mesoporous pores shown by the hysteresis loop in the Ar adsorption isotherm.

The SEM-EDS data gave the $\mathrm{Si} / \mathrm{Al}$ ratio of the sample as 0.24 . Assuming that the acidity of the SAPO zeolite was due to the substitution of a P atom by a Si atom, the amount of Si atoms would give the amount of acid sites. This gave the calculated
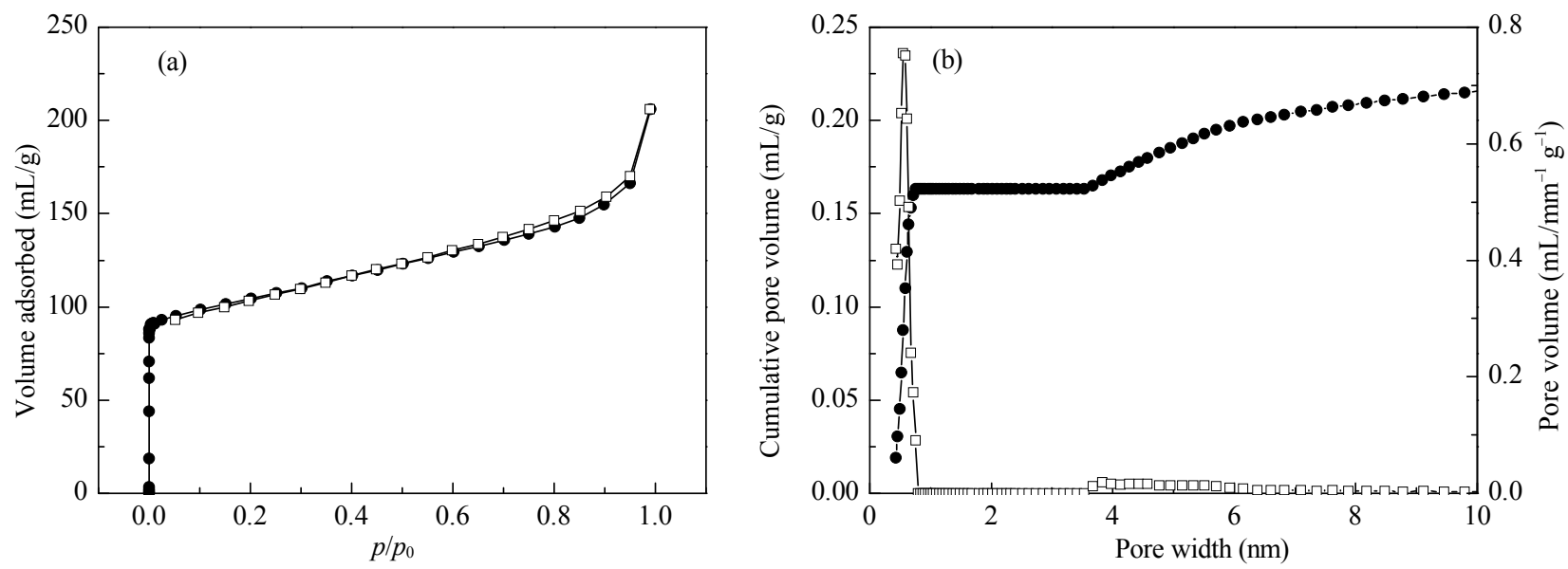

Fig. 4. Argon adsorption isotherm for the SAPO-34 zeolite (a) and its pore size distribution calculated by the DFT method (b). 


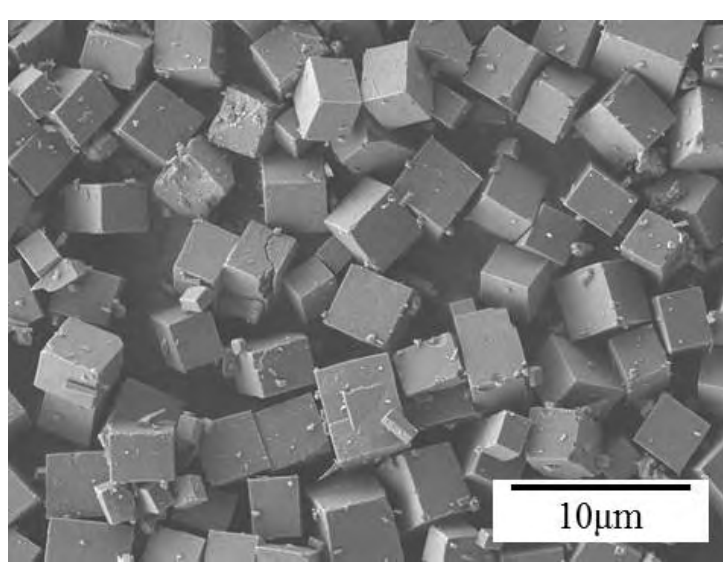

Fig. 5. SEM image of the SAPO-34 zeolite.

acid site density as $0.99 \mathrm{mmol} / \mathrm{g}$. In addition, $\mathrm{NH}_{3}$ - TPD measurement was performed to characterize the acid site density. In the $\mathrm{NH}_{3}$-TPD profile, which is shown in Fig. 6, two desorption peaks were identified at $121{ }^{\circ} \mathrm{C}\left(l\right.$-peak) and $426^{\circ} \mathrm{C}$ ( $h$-peak). This profile was curve fitted by Gaussian functions, which quantified the site densities of the $l$-peak and $h$-peak to be 0.97 and $1.01 \mathrm{mmol} / \mathrm{g}$, respectively. The latter peak has been suggested for use as a measure of the acid sites of a zeolite by Niwa et al. [11], who argued that because the l-peak is due to $\mathrm{NH}_{3}$ adsorbed weakly on $\mathrm{NH}_{4}{ }^{+}$cations adsorbed on Brønsted acid sites and also because its intensity depended on the experiment conditions, the intensity of the $l$-peak does not provide useful characterization data. On the other hand, the $h$-peak in the desorption profile of $\mathrm{NH}_{3}$ was shown to be due to $\mathrm{NH}_{3}$ adsorbed on the acid sites, and its intensity was independent of the experiment conditions. Thus, the desorption amount calculated from the $h$-peak area was used for the acid site density. The SEM-EDS and $\mathrm{NH}_{3}$-TPD data both were in agreement that the sample has an acid site density of $1.0 \mathrm{mmol} / \mathrm{g}$.

\subsection{Methanol and DME adsorption isotherms of the SAPO-34}

The curves of the differential heats of adsorption versus adsorbed amount (calorimetric curve) of methanol and DME

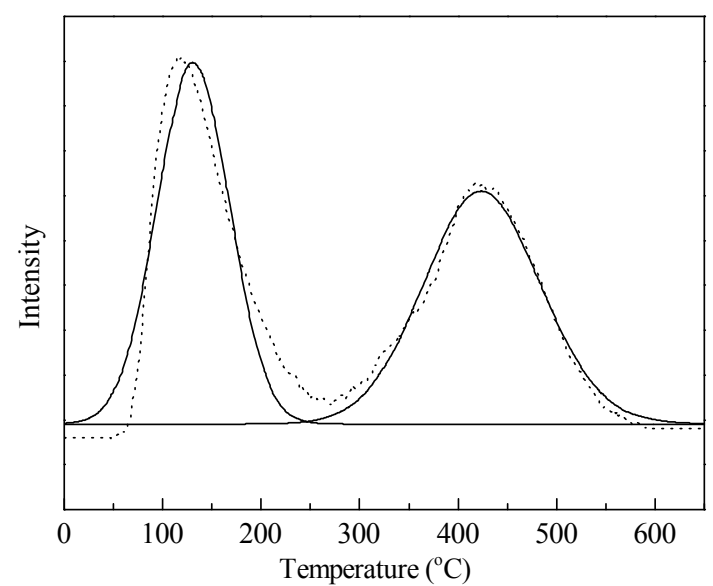

Fig. 6. $\mathrm{NH}_{3}$-TPD profile (bold line) for the SAPO-34 zeolite. Thin lines are curve fitted by Gaussian functions.

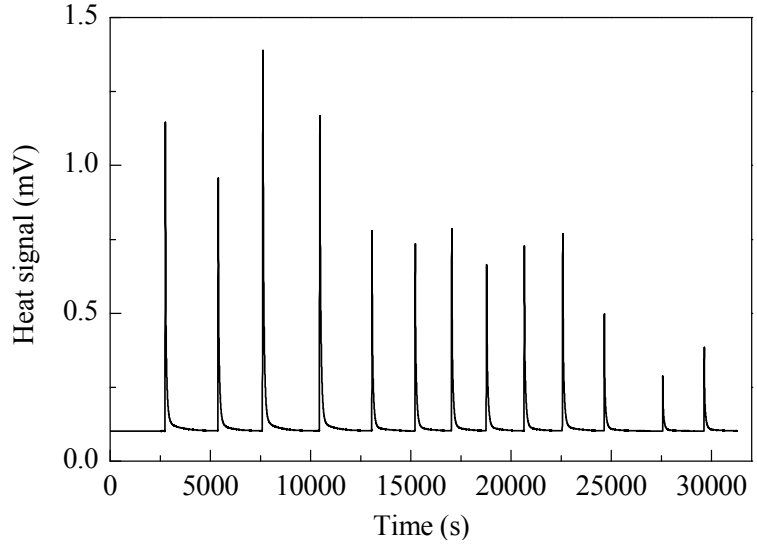

Fig. 7. Heat responses during methanol adsorption at $25^{\circ} \mathrm{C}$.

were measured at the same time as the adsorption isotherms. Some typical heat response curves recorded during the methanol adsorption experiment at $25{ }^{\circ} \mathrm{C}$ are presented in Fig. 7. Quite rapid heat responses and a stable baseline were observed. Lee et al. [12] reported that equilibrium was not achieved in their thermograms when adsorbates such as methanol and diethyl ether were dosed into a H/ZSM-5 zeolite at temperatures lower than $127{ }^{\circ} \mathrm{C}$ due to chromatographic adsorption, but in our calorimeter, the SAPO-34 zeolite gave very quick thermal equilibrium even at room temperature. Figure 8 shows typical pressure and heat signals obtained when a small amount of DME was dosed into the sample cell at $25{ }^{\circ} \mathrm{C}$. In the methanol and DME adsorption experiments, the pressure in the sample cell quickly reached equilibrium within $50 \mathrm{~s}$ in each dose, and in 300 to $400 \mathrm{~s}$ for the heat response.

Figure 9 shows methanol adsorption isotherms and the corresponding calorimetric curves measured at 25,60 , and 100 ${ }^{\circ} \mathrm{C}$. The methanol isotherms showed that a finite amount of methanol was irreversibly adsorbed on the sample at zero pressure (indicated as portion 1). An irreversible adsorption of methanol on SAPO-34 has also been observed in a previous report [13]. The irreversibly adsorbed amount decreased with increasing adsorption temperature because desorption becomes faster at a higher temperature. The irreversible ad-

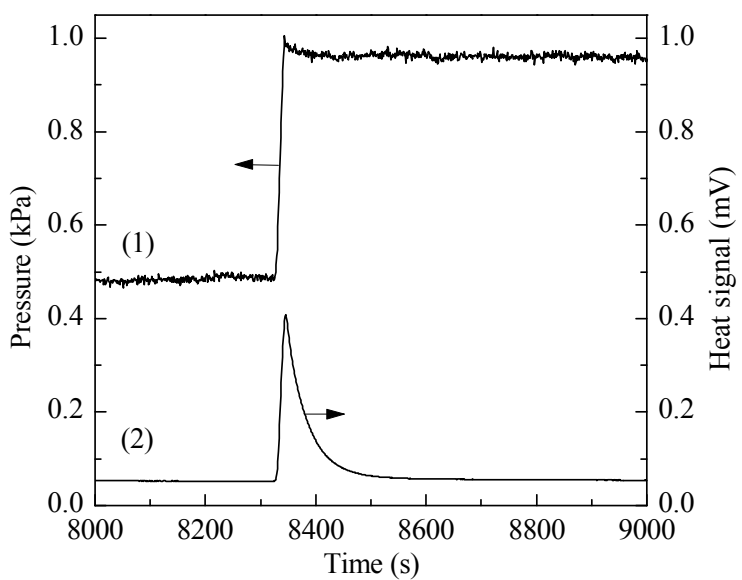

Fig. 8. Typical pressure (1) and heat response (2) changes from a small amount of DME dosed into the sample cell at $25^{\circ} \mathrm{C}$. 

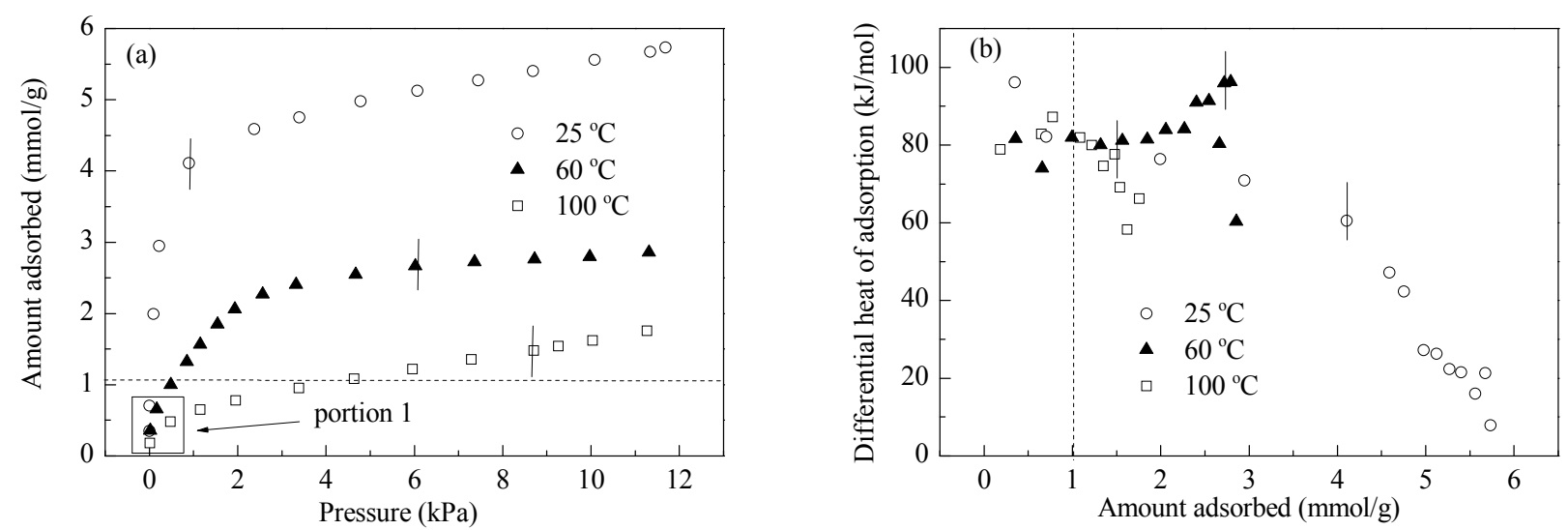

Fig. 9. Methanol adsorption isotherms (a) and calorimetric curves (b) at 25,60 , and $100{ }^{\circ} \mathrm{C}$. Vertical lines indicate the saturation amount where heat drops occurred. Dotted lines show the acid site density of $1.0 \mathrm{mmol} / \mathrm{g}$ of the SAPO-34.

sorbed amounts ( $\left.N_{\text {ad,irr }}\right)$ at each temperature are summarized in Table 1, along with the total saturation amounts ( $\left.N_{\text {ad,total,sat }}\right)$ and reversibly adsorbed saturation amounts $\left(N_{\text {ad,sat }}\right)$. $N_{\text {ad,sat }}$ was obtained by subtracting $N_{\text {ad,irr }}$ from $N_{\text {ad,total,sat }}$ after first verifying that this gave a value of $\mathrm{N}_{\mathrm{ad} \text {,sat }}$ that was about the same as that obtained from a second measurement of the isotherm after evacuation of the sample cell, to remove reversibly adsorbed methanol, following the first measurement of the isotherm.

The saturation amounts were estimated from the calorimetric curves using an interpretation given by Auroux [14], who suggested that the saturation amount is the coverage where a quick drop in the calorimetric curve was observed when adsorption was performed at a high enough adsorption temperature to ensure sufficient mobility. This is because when adsorbed species have sufficient mobility to freely move around, they adsorb on the strongest sites first, and then the next stronger sites are successively occupied until all sites are occupied. For methanol adsorption at $25{ }^{\circ} \mathrm{C}$, the differential heat first gradually decreased with coverage until $4.11 \mathrm{mmol} / \mathrm{g}$ and then there was a steep decrease. The comparison of this curve with the two other curves at the higher temperatures suggests that the initial gradual decrease can be considered to be a plateau where the heat of adsorption is constant. It was not quite a plateau but instead showed a slight decrease versus coverage because the temperature was still a bit too low for fully mobile adsorbed species, such that to some extent, some weaker adsorption sites were also simultaneously populated together with the regular adsorption sites. On the other hand, at the higher temperatures, a clear plateau at $80 \pm 5 \mathrm{~kJ} / \mathrm{mol}$ was observed at low coverages. At the coverages of 2.55 and 1.48 $\mathrm{mmol} / \mathrm{g}$ for 60 and $100{ }^{\circ} \mathrm{C}$ calorimetric curves, respectively, the heat quickly decreased, which indicated that these were the saturation coverages. In the calorimetric curve of $60^{\circ} \mathrm{C}$, a heat rise was observed just before the heat drop. A heat rise is often due to adsorbed species interaction and had been seen by Ferreira and coworkers on MFI zeolite [15] and by Rouquerol et al. [16].

Because the saturation coverage was taken to be the adsorbed amount where the rapid heat drop was observed, further amounts adsorbed were attributed to adsorption on weaker adsorption sites with much smaller heats of adsorption. From the heat drop in the calorimetric curves, the saturation coverages of methanol at 25,60 , and $100{ }^{\circ} \mathrm{C}$ were $4.11,2.55$, and $1.48 \mathrm{mmol} / \mathrm{g}$, respectively. These values were all larger than that the acid site density $(1.0 \mathrm{mmol} / \mathrm{g})$ of the sample, that is, the adsorption stoichiometry was $>1.0$. The nature of adsorbed methanol complexes on zeolites has been reported in several papers $[12,13,17,18]$, where it was discussed that adsorbed methanol possibly existed as neutral hydrogen-bonded molecules rather than positively charged protonated carbocations. A saturation amount of methanol that was in excess of the acid site concentration has been previously observed with a H-ZSM-5 zeolite where the saturation coverage was given as 2 molecules/site at $127^{\circ} \mathrm{C}$. This was analyzed as being due to the formation of methanol clusters stabilized by hydrogen bond networks because alcohols can be both hydrogen bond donors and hydrogen bond acceptors [12]. Quantum chemical calculations $[17,18]$ also showed that methanol can be molecularly adsorbed (hydrogen-bonded) on H/SAPO-34, instead of being protonated to form a carbocation. The calculated adsorption heat of the second methanol on SAPO-34 was $77.8 \mathrm{~kJ} / \mathrm{mol}$, which was very close to that for the first molecule, $84.7 \mathrm{~kJ} / \mathrm{mol}$. Therefore, the coverage in excess of the acid site density could be due to the localized clustering of methanol in SAPO-34. In this work, a constant adsorption heat of $80 \pm 5 \mathrm{~kJ} / \mathrm{mol}$ was measured in the calorimetric curves at 60 and $100{ }^{\circ} \mathrm{C}$. This experimental value is comparable to the calculated values. However, as compared to H-ZSM-5, a smaller amount of methanol

Table 1

Total saturation $\left(N_{\text {ad,total,sat }}\right)$, irreversibly adsorbed $\left(N_{\text {ad,irr }}\right)$, and reversibly adsorbed saturation $\left(N_{\text {ad,sat }}\right)$ amounts.

\begin{tabular}{|c|c|c|c|c|c|c|}
\hline \multirow{2}{*}{$T\left({ }^{\circ} \mathrm{C}\right)$} & \multicolumn{2}{|c|}{$N_{\text {ad,total,sat }}(\mathrm{mmol} / \mathrm{g})$} & \multicolumn{2}{|c|}{$N_{\text {ad,irr }}(\mathrm{mmol} / \mathrm{g})$} & \multicolumn{2}{|c|}{$N_{\text {ad,sat }}(\mathrm{mmol} / \mathrm{g})$} \\
\hline & Methanol & DME & Methanol & DME & Methanol & DME \\
\hline 25 & 4.11 & 2.2 & 0.80 & 0.70 & 3.31 & 1.50 \\
\hline 60 & 2.55 & 1.84 & 0.33 & 0.49 & 2.22 & 1.35 \\
\hline 100 & 1.48 & 1.25 & 0.17 & 0.30 & 1.31 & 0.95 \\
\hline
\end{tabular}



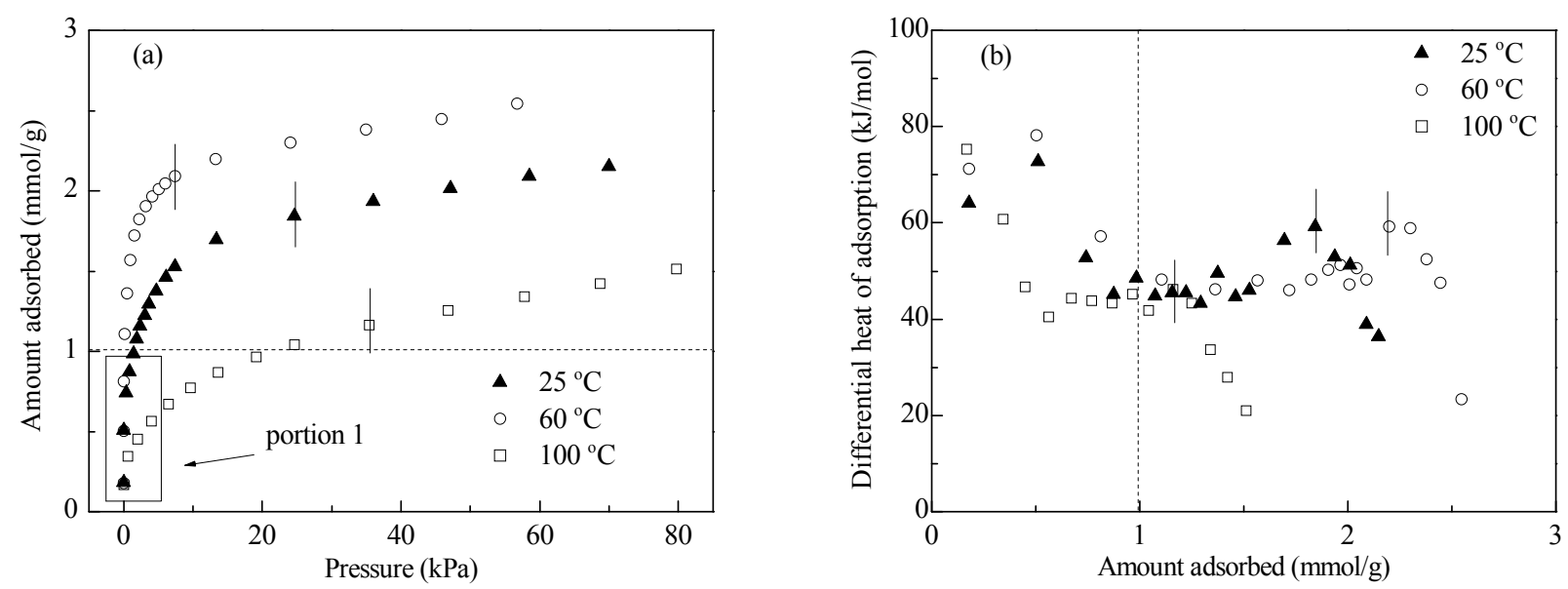

Fig. 10. DME adsorption isotherms (a) and calorimetric curves (b) at 25,60 , and $100{ }^{\circ} \mathrm{C}$. Vertical lines indicate the saturation amounts where heat drops occurred. Dotted lines show the acid site density of $1.0 \mathrm{mmol} / \mathrm{g}$ of the SAPO-34.

was adsorbed on SAPO-34. This may be because its cage structure limits the methanol cluster size in the cage, as suggested by Bordiga et al. [13].

Figure 10 shows the results of DME adsorption on SAPO-34. There are similarities to the methanol adsorption isotherm: there was irreversible adsorption and a portion of the calorimetric curve showed a heat rise trend. The details of the calorimetric curves were that the adsorption heat first gradually decreased to $45 \mathrm{~kJ} / \mathrm{mol}$ until the coverage of $1.0 \mathrm{mmol} / \mathrm{g}$, after which there was a flat plateau at $45 \mathrm{~kJ} / \mathrm{mol}$, and then quick heat drops were observed at 2.20,1.84 and $1.25 \mathrm{mmol} / \mathrm{g}$ for the 25 , 60 and $100{ }^{\circ} \mathrm{C}$ calorimetric curves, respectively. As compared to methanol adsorption, smaller amounts of DME were adsorbed, but which were again more than the acid site density. Although it is unlikely that DME would form clusters stabilized by hydrogen bonding, tentatively, the data were interpreted as that DME adsorption also occur with more than one molecule per acid site. In addition, and also similar to methanol, there was another adsorption site in the zeolite, which was revealed by that adsorption continued to higher coverages after the rapid heat decrease. The irreversibly adsorbed amounts, total saturation amounts and reversibly adsorbed saturation amounts of DME are summarized in Table 1.

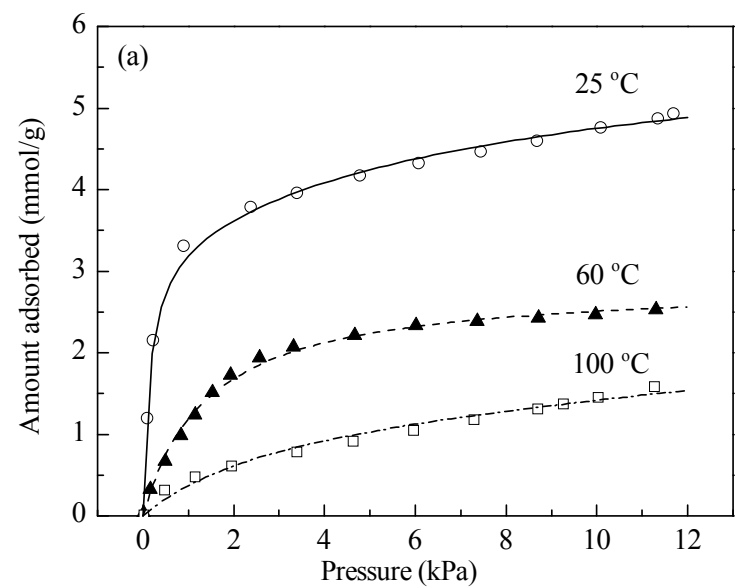

\subsection{Langmuir parameters obtained from the isotherms}

The vertical lines shown in the adsorption isotherms at the different temperatures in Fig. 9(a) and Fig. 10(a) indicate the amounts adsorbed up to where there was a rapid heat drop in the calorimetric curves. The much smaller heat of adsorption to the right side of the line segments indicated that the adsorption there can no longer be associated with adsorption on the regular sites. Thus, these regions should not be used as part of the adsorption isotherm for the regular adsorption sites during curve fitting. In the absence of the calorimetric data, these regions would have been assumed to be part of the adsorption isotherm for the regular adsorption sites, which would be erroneous. In this work, in order to account for the existence of another weaker adsorption site which continued to be populated at high pressures, in addition to the regular adsorption site, the dual-site Langmuir (DSL) equation was used.

In addition, because an adsorption isotherm is only applicable to reversible adsorption, the data points used to curve fit to get the Langmuir parameters should exclude irreversibly adsorbed adsorbate. This was done by subtracting the amount irreversibly adsorbed at zero pressure in the isotherms. In fit-

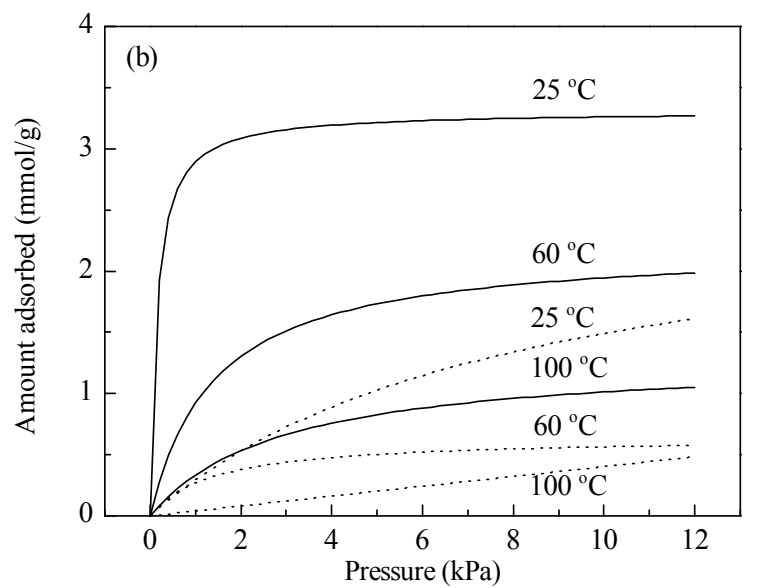

Fig. 11. (a) Isotherms of reversibly adsorbed methanol at 25,60 , and $100{ }^{\circ} \mathrm{C}$ and the curves fitted by the dual-site Langmuir equation (lines). (b) Fitted isotherms of the first site (solid lines) and second site (dotted lines) at 25,60 , and $100{ }^{\circ} \mathrm{C}$. 

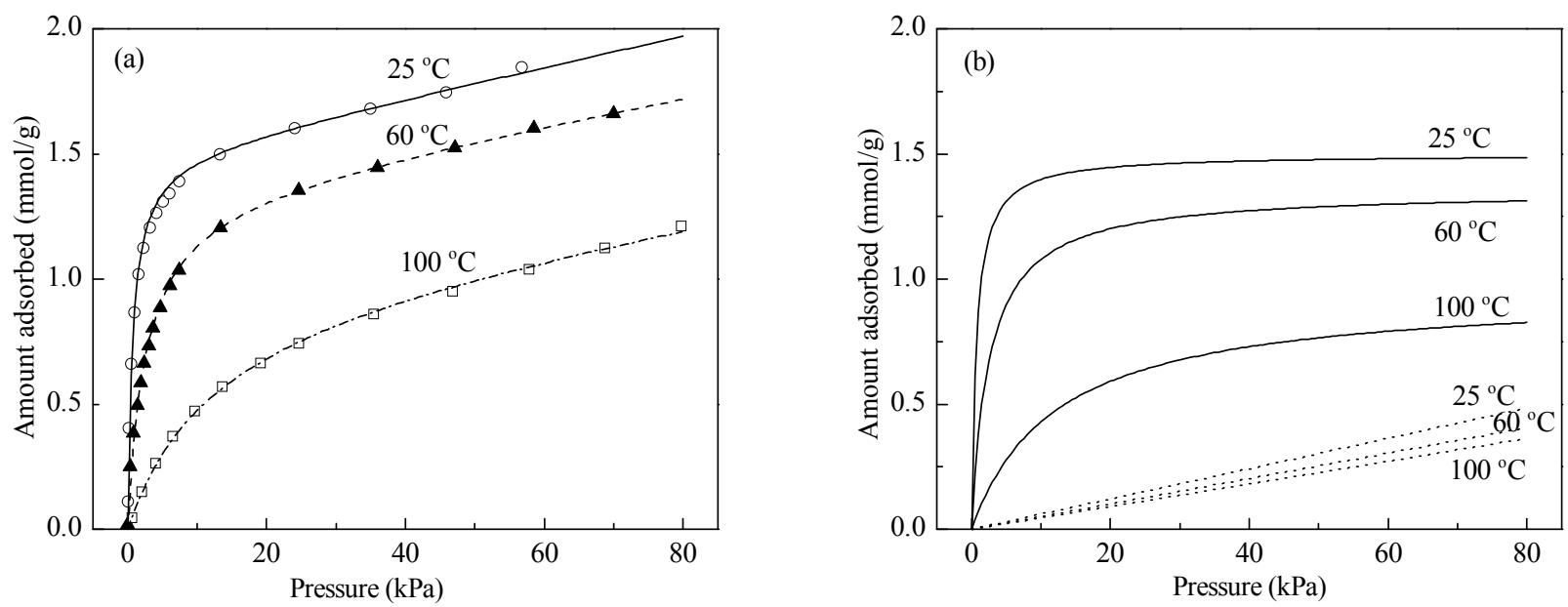

Fig. 12. (a) Isotherms of reversibly adsorbed DME at 25,60 , and $100{ }^{\circ} \mathrm{C}$ and the curves fitted by the dual-site Langmuir equation (lines). (b) Fitted isotherms of the first site (solid lines) and second site (dotted lines) at 25,60 , and $100{ }^{\circ} \mathrm{C}$.

ting the data points to the DSL equation, the reversibly adsorbed saturation amounts shown in Table 1 were used as the

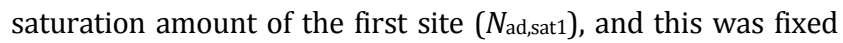
as a non-adjustable parameter. That is, the curve fitting used three adjustable parameters, which were the saturation amount of the second site $\left(N_{\text {ad,sat2 } 2}\right)$ and the adsorption equilibrium constants of the first and second sites ( $b_{1}$ and $\left.b_{2}\right)$. Curve fitting using the single-site Langmuir (SSL) equation was also done for comparison, but the fits were not satisfactory, esp. at higher pressures. The fitted DSL curves are shown in Fig. 11(a) for methanol and Fig. 12(a) for DME. The fitted isotherms of the first and second sites of the DSL are shown in Fig. 11(b) and 12(b). The Langmuir parameters are summarized in Table 2.

The saturation amounts decrease as the temperature increased. This indicated that the data obtained was not the acid site density, which would not change with temperature. On the one hand, this is in agreement with the interpretation that more than one molecule was adsorbed on one site because the higher temperature data are consistent with a decrease in adsorption stoichiometry. On the other hand, this indicated the unfortunate situation that the low temperature adsorption isotherms do not unambiguously provide data on the acid site density of the zeolite, which is one of the important use of an adsorption isotherm.

\section{Conclusions}

The adsorption isotherms and calorimetric curves were simultaneously measured during the adsorption of methanol and DME on a SAPO- 34 zeolite at 25,60 , and $100{ }^{\circ} \mathrm{C}$. The calorimetric curves were used to get the saturation coverages, which were the coverages where these curves gave abrupt drops in the heat of adsorption. The adsorption stoichiometry was larger than one, and it decreased with temperature. Further adsorption occurring after the heat drops in the calorimetric curves showed that there were other weaker sites. The Langmuir parameters for the two types of sites were obtained by curve fitting with the dual-site Langmuir equation, while the Langmuir equation for single sites could not give good fits, esp. in the high pressure region where adsorption mainly occurred on weaker sites.

\section{References}

[1] Do D D. Adsorption Analysis: Equilibria and Kinetics. London: Imperial College Press, 1998

[2] Chen D, Rebo H P, Moljord K, Holmen A. Ind Eng Chem Res, 1999, 38: 4241

[3] Solinas V, Ferino I. Catal Today, 1998, 41: 179

Table 2

Parameters of single-site Langmuir (SSL) and dual-site Langmuir (DSL) equations.

\begin{tabular}{|c|c|c|c|c|c|c|c|c|c|}
\hline \multirow{2}{*}{$T\left({ }^{\circ} \mathrm{C}\right)$} & \multirow{2}{*}{$\begin{array}{c}\text { Adsorbate } \\
\text { gas }\end{array}$} & \multicolumn{3}{|c|}{ SSL } & \multicolumn{5}{|c|}{ DSL } \\
\hline & & $N_{\text {ad,sat }}(\mathrm{mmol} / \mathrm{g})$ & $b\left(\mathrm{kPa}^{-1}\right)$ & $R^{2}$ & $N_{\text {ad,sat1 }}(\mathrm{mmol} / \mathrm{g})$ & $b_{1}\left(\mathrm{kPa}^{-1}\right)$ & $N_{\text {ad,sat2 }}(\mathrm{mmol} / \mathrm{g})$ & $b_{2}\left(\mathrm{kPa}^{-1}\right)$ & $R^{2}$ \\
\hline \multirow[t]{2}{*}{25} & Methanol & 4.70 & 3.08 & 0.953 & 3.31 & 7.01 & 2.72 & 0.12 & 0.994 \\
\hline & DME & 1.68 & 0.96 & 0.964 & 1.50 & 1.39 & $4.32 \times 10^{4}$ & $1.40 \times 10^{-7}$ & 0.995 \\
\hline \multirow[t]{2}{*}{60} & Methanol & 2.86 & 0.72 & 0.996 & 2.22 & 0.72 & 0.64 & 0.72 & 0.996 \\
\hline & DME & 1.64 & 0.27 & 0.987 & 1.35 & 0.39 & $1.01 \times 10^{3}$ & $5.04 \times 10^{-5}$ & 0.998 \\
\hline \multirow[t]{2}{*}{100} & Methanol & 2.11 & 0.20 & 0.971 & 1.31 & 0.34 & $4.07 \times 10^{4}$ & $9.93 \times 10^{-7}$ & 0.982 \\
\hline & DME & 1.46 & 0.05 & 0.992 & 0.95 & 0.082 & $3.20 \times 10^{3}$ & $1.42 \times 10^{-5}$ & 0.999 \\
\hline
\end{tabular}




\title{
Graphical Abstract
}

Chin. J. Catal., 2013, 34: 2192-2199 doi: 10.1016/S1872-2067(12)60676-7 Adsorption isotherms of methanol and dimethyl ether on SAPO-34
measured together with differential adsorption heat measurement

Yasukazu Kobayashi, Yuxin Li, Yao Wang, Dezheng Wang * Tsinghua University

Adsorption of methanol and dimethyl ether on SAPO-34 needs to be fitted by the dual-site Langmuir isotherms for acid sites (site 1) and physisorption sites (site 2).

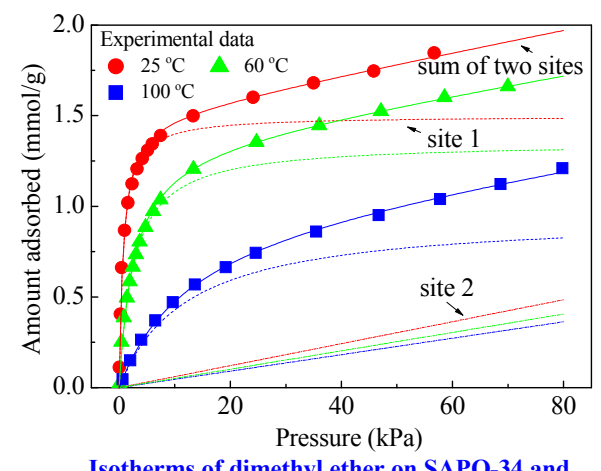

Isotherms of dimethyl ether on SAPO-34 and fitted dual-site isotherms
[4] Farneth W E, Gorte R J. Chem Rev, 1995, 95: 615

[5] Auroux A. Mol Sieves, 2008, 6: 45

[6] Cardona-Martinez N, Dumesic J A. Adv Catal, 1992, 38: 149

[7] Olsbye U, Svelle S, Bjørgen M, Beato P, Janssens T V W, Joensen F, Bordiga S, Lillerud K P. Angew Chem Int Ed, 2012, 51: 5810

[8] Li W J, Wang Y, Wang D Z, Wei F. Chin J Catal (李文俊, 王圭, 王德 峥, 魏飞. 催化学报), 2006, 27: 200

[9] Handy B E, Sharma S B, Spiewak B E, Dumesic J A. Meas Sci Technol, 1993, 4: 1350

[10] Treacy M M J, Newsam J M, Deem M W. Proc R Soc Lond A, 1991, 433: 499

[11] Niwa M, Katada N, Okumura K. Characterization and Design of
Zeolite Catalysts. London: Springer, 2010

[12] Lee C C, Gorte R J, Farneth W E.J Phys Chem B, 1997, 101: 3811

[13] Bordiga S, Regli L, Lamberti C, Zecchina A, Bjørgen M, Lillerud K P. J Phys Chem B, 2005, 109: 7724

[14] Auroux A. Top Catal, 1997, 4: 71

[15] Ferreira A F P, Mittelmeijer-Hazeleger M C, Bliek A. Microporous Mesoporous Mater, 2006, 91: 47

[16] Rouquerol J, Partyka S, Rouquerol F. J Chem Soc, Faraday Trans 1, 1977, 73: 306

[17] Shah R, Gale J D, Payne M C. Chem Commun, 1997: 131

[18] Gale J D, Shah R, Payne M C, Stich I, Terakura K. Catal Today, 1999, 50: 525

\section{SAPO-34上甲醇及二甲醚吸附等温线及吸附热测量与分析}

\author{
Yasukazu Kobayashi，李玉新，王 圭，王德峥* \\ 清华大学化学工程系, 北京 100084
}

摘要: 在 25,60 和 $100{ }^{\circ} \mathrm{C}$ 下分别测定了甲醇及二甲醚在SAPO-34分子笁上的吸附等温线, 同时用微量热法测定了微分吸附热与覆 盖率的关系曲线(量热线), 提出了吸附数据需要利用双吸附位Langmuir方程拟合, 并获取了相应的吸附参数. 对比测得的吸附等 温线与量热线发现, 在一定压力下, 当甲醇及二甲醚在SAPO-34上达到一定吸附量后, 随着吸附质分压增加, 量热线快速下降, 而 吸附等温线显示出吸附量仍然继续增加. 由此推断, 在SAPO-34分子篮上存在两种吸附位一一常规吸附位及弱吸附位, 其中弱吸 附位在高分压下继续吸附. 如缺乏量热数据提供的常规吸附位饱和吸附量数据, 对吸附等温线进行单吸附位拟合获取吸附参数 极易导致错误结果,尤其是当吸附质分压较高时. 建议采用双吸附位Langmuir方程, 参照量热线提供的常规吸附位的饱和吸附量, 通过拟合可以获得两种吸附位的吸附参数.

关键词：双吸附位Langmuir方程; 甲醇吸附; 二甲醚吸附; 吸附热; SAPO-34

收稿日期: 2013-06-30. 接受日期: 2013-08-13. 出版日期: 2013-12-20.

*通讯联系人. 电话: (010)62794467; 传真: (010)62772051; 电子信箱: wangdezheng@tsinghua.edu.cn 基金来源: 国家自然科学基金(21173125).

本文的英文电子版由Elsevier出版社在ScienceDirect上出版(http://www.sciencedirect.com/science/journal/18722067). 